\title{
Characterization of Staphylococcus sciuri sp.nov. and Its Subspecies ${ }^{1}$
}

\author{
WESLEY E. KLOOS, KARL H. SCHLEIFER, AND RODNEY F. SMITH \\ Department of Genetics, North Carolina State University, Raleigh, North Carolina 27607; Lehrstuhl für \\ Mikrobiologie, Technische Universität München, 3 Munich 2, Germany; and Public Health Laboratory \\ Services, Contra Costa County Health Department, Martinez, California 94553
}

Several strains previously classified as group III staphylococci, by the scheme of Schleifer and Kocur, and numerous strains isolated from animal and human skin that appeared to be related to group III strains were subjected to a taxonomic study. As a result of this study, all group III and related strains were placed in the newly proposed species Staphylococcus sciuri. This species can be differentiated from all other staphylococci on the basis of colony morphology, cell wall peptidoglycan, acid production from cellobiose and usually from fucose under aerobic conditions, and a combination of other characteristics. Thirty-five strains that produced large colonies, usually moderate to light anaerobic growth in thioglycolate, and acid from galactose, sucrose, glycerol, and often from melezitose were placed in the type subspecies, $S$. sciuri subsp. sciuri. Nine strains that produced very small, unpigmented colonies, usually no detectable anaerobic growth in thioglycolate, and acid from sucrose and often from galactose, glycerol, lactose, and raffinose were placed in the subspecies $S$. sciuri subsp. lentus. The type strains of these subspecies are ATCC 29062 and ATCC 29070 , respectively. A group of three strains that produced relatively small, unpigmented colonies, moderate anaerobic growth in thioglycolate, and acid from glycerol but failed to produce acid from sucrose, melezitose, raffinose and usually galactose may also deserve subspecies status. A summary of the character variation found in $S$. sciuri and in other novobiocin-resistant species and a simplified scheme for distinguishing $S$. sciuri and its subspecies are included in this paper.

In 1973, Schleifer and Kocur (13) recognized a group of nine strains of staphylococci that contained a unique cell-wall peptidoglycan type, LLys-L-Ala-Gly ${ }_{4}$, and formed L-lactic acid from glucose under anaerobic conditions. According to their classification scheme, based on peptidoglycan type, teichoic acid type, configuration of lactic acid, and $\mathrm{pH}$ values of a glucose medium after anaerobic incubation, these strains were placed in Staphylococcus groups IIIA, B, and C. More recent studies by Kocur and Boháček (7) have determined that the guanine plus cytosine $(\mathrm{G}+\mathrm{C})$ contents of the deoxyribonucleic acids (DNA) of several of the strains in group IIIA are in the range of 29.8 to $33.3 \mathrm{~mol} \%$. One of the strains (CCM 2614; I3) in group IIIC was previously designated as Staphylococcus lactis by Davison and co-workers (1-3); however, since the name $S$. lactis is a later objective synonym of Micrococcus varians Migula 1900 (8), it cannot be appropriately applied to staphylococci. To date, staphylococci in group III have remained in an uncertain taxonomic status.

In independent studies characterizing staphy-

1 Paper no. 4817 of the Journal Series of the North Carolina Agricultural Experiment Station, Raleigh, N.C. 27607 lococci from animal and human skin, we have isolated certain strains that could not be identified with currently recognized species of Staphylococcus, namely, $S$. aureus, S. simulans, S. xylosus, S. cohnii, S. saprophyticus, S. haemolyticus, S. warneri, $S$. hominis, $S$. epidermidis, and $S$. capitis $(4,12)$. Interestingly, a large number of these strains isolated from animal skin and several isolated from human skin had the same peptidoglycan type and produced the same lactic acid isomer as members of group III.

Since numerous strains of group III staphylococci are now available for analysis, we proceeded, in the presently reported study, to determine the taxonomic status of this unique group.

\section{MATERIALS AND METHODS}

Bacterial strains. Representative strains of Staphylococcus group III (13) used in this study included CCM 2611 (J896) obtained from L. Janícková, State Veterinary Institute, Prague, CSSR, and isolated from milk, CCM 2614 (I3) isolated from the uropygeal gland of a chicken and CCM 2615 (A4) obtained from A. R. Archibald, Newcastle, England; and CCM 2598 (K2), CCM 2599 (K6), K14, K15, K17, $\mathrm{K} 18, \mathrm{~K} 19, \mathrm{~K} 20$, and $\mathrm{K} 21$ obtained from M. Roguinsky, Nouzilly, France, and isolated from goat udders. 
A total of 35 strains were isolated from the healthy skins of Eastern gray squirrels (Sciurus carolinensis), Southern flying squirrels (Glaucomys volans), opossums (Didelphis virginiana), a raccoon (Procyon lotor), a dog (Canis familiarus), sheep (Ovis aries), and humans (Table 1). Three strains were also isolated from marsh grass (Spartina alternaflora) and beach sand frequented by animals.

For comparative purposes, 64 strains of the presumed related species, Staphylococcus xylosus, and 20 strains of $S$. cohnii were isolated from the abovementioned animals and were characterized.

Procedures for isolating staphylococci. The sampling techniques and the isolation medium used were described previously $(4,6,12)$.

Culture conditions. Culture conditions were similar to those described previously for the study of cutaneous micrococci (6).

Character determinations. Procedures for determining DNA base composition, colony morphology and pigment, cell morphology, motility, aerobic and anaerobic growth in thioglycolate, salt tolerance, growth temperature, catalase and benzidine activities, acetylmethylcarbinol production, nitrate reduction, coagulase, hemolysis, deoxyribonuclease (DNase), phosphatase, and bacteriolytic activity, carbohydrate reactions, and susceptibility to various antibiotics, lysozyme, and lysostaphin were similar to those described previously for cutaneous micrococci and staphylococci $(5,6,12)$.

Procedures for determining gelatinase and lecithinase (egg yolk reaction) activity, hydrolysis of Tween 80 , and lipase activity on tributyrin and triolein agars were described previously (14). Casein hydrolysis was determined with the medium of Martley et al. (9). Elastase activity was determined by the method of Varadi and Saqueton (15).

Procedures for making cell wall hydrolysates and determining peptidoglycan type, teichoic acid, configuration of lactic acid, and the anaerobic fermentation of glucose have also been described previously $(10,11,13,15)$. The amount of free glycerol was enzymatically determined in acid hydrolysates (2 $\mathrm{N} \mathrm{HCl}, 100 \mathrm{C}, 3 \mathrm{~h}$ ) of extracted teichoic acids. The amount of glycerol mono- and diphosphates was not determined by this method. The different peptidoglycan types are abbreviated according to the system of Schleifer and Kandler (11).

Chemicals. Egg-white lysozyme (muramidase), triolein, elastin, and phenolphthalein monophosphate were purchased from Sigma Chemical Co., St. Louis, Mo.; lysostaphin was from Schwarz/Mann, Orangeburg, N.Y.; $\alpha$-naphthylamine was from Matheson Coleman and Bell, Cincinnati, Ohio; 4aminoantipyrine was from $\mathrm{K} \& \mathrm{~K}$ Laboratories, Inc., Plainview, N.Y.; penicillin G and tetracycline hydrochloride were purchased from Calbiochem, Los Angeles, Calif. Erythromycin base was kindly supplied by Abbott Laboratories, North Chicago, Ill., and novobiocin was kindly supplied by the Upjohn Co., Kalamazoo, Mich.

\section{RESULTS AND DISCUSSION}

Characterization of S. sciuri sp. nov. and its subspecies. Staphylococci examined in this study that were novobiocin resistant, produced acid from $D-(+)$-cellobiose and usually from $D$ (+)-fucose, produced only the L-lactic acid isomer from glucose, and contained cell wall peptidoglycan of the type L-Lys-L-Ala-Gly ${ }_{4}$ were clearly different from previously described species $(4,12)$. These staphylococci are considered here as members of a new species, Staphylococcus sciuri (sci'ur-i. L. mas.n. Sciurus generic name of a squirrel on whose skin this species is commonly found in large populations; L. gen.n. sciuri of the squirrel). Strains that produced large distinctive colonies, failed to produce acid from raffinose and usually $\alpha$-lactose, but often produced acid from $\mathrm{D}(+)$-melezitose, and were usually pigmented (Table 1) were placed in $S$. sciuri subsp. sciuri. The $\mathrm{K}$ series of strains isolated from goats that produced slow-growing, small colonies, usually produced acid from raffinose and $\alpha$-lactose but no acid from $\mathrm{D}-(+)$ melezitose, and were unpigmented were placed in S. sciuri subsp. lentus (len'tus. L. adj. lentus slow; pertaining to slow growth). Strains CCM 2611, CCM 2614, and CCM 2615 appear to be related to both subspecies but differ from them in several distinctive characteristics and combinations of characteristics and, therefore, may belong to a different subspecies. Further studies are needed to resolve this matter.

At present, we have chosen to divide the species $S$. sciuri into at least two subspecies rather than to make proposals for separate species. This choice is somewhat arbitrary, but it is based primarily on the unique characteristics that are shared by these staphylococci. However, as staphylococci from more animal species are studied, we could conceivably find that what appear at present to be unique characters may actually be rather common in nature. To date, most of our knowledge about staphylococci has come from the analysis of human and certain domestic-animal strains. Also, in this study we have been reluctant to assign $S$. sciuri subsp. lentus a higher taxonomic rank because of the limited source and number of strains available for analysis. As additional sources and strains of this subspecies are studied, we should be better able to evaluate the difference in character parameters observed between this organism and $S$. sciuri subsp. sciuri. Future DNA hybridization studies may also be helpful in evaluating the genetic relationship of these organisms.

The following description of $S$. sciuri is based on a total of 44 strains (35 strains of $S$. sciuri subsp. sciuri and 9 strains of $S$. sciuri subsp. lentus), unless otherwise noted.

Cells were gram-positive cocci, 0.7 to $1.2 \mu \mathrm{m}$ in diameter, nonmotile, and nonsporeforming, and occurred singly, in pairs, and tetrads. 
TABLE 1. Sources of Staphylococcus sciuri subsp. sciuri strains studied

\begin{tabular}{|c|c|c|c|c|}
\hline Strain & $\begin{array}{l}\text { Host animal (skin) or other } \\
\text { habitat }\end{array}$ & Animal no. & Collection location & $\begin{array}{l}\text { Collection } \\
\text { date }\end{array}$ \\
\hline SC 120 & $\begin{array}{l}\text { Eastern gray squirrel } \\
\quad \text { (Sciurus carolinensis) }\end{array}$ & 11 & $\begin{array}{l}\text { Sunbury, N.C., } \\
\text { woodland }\end{array}$ & $8 / 72$ \\
\hline ATCC 29062, SC 114 & & 13 & & \\
\hline SC 231 & & 23 & $\begin{array}{l}\text { Raleigh, N.C., } \\
\text { residential }\end{array}$ & 9/72 \\
\hline SC 255 & & 24 & & \\
\hline SC 226 & & 25 & & \\
\hline SC 251 & & 26 & & \\
\hline SC $407,-409$ & & 38 & $\begin{array}{l}\text { Sunbury, N.C., } \\
\text { swamp }\end{array}$ & $12 / 72$ \\
\hline $\begin{array}{l}\text { SC } 414 \\
\text { SC } 446,-474\end{array}$ & & 39 & & \\
\hline $\begin{array}{l}\text { SC 446, }-474 \\
\text { GV } 234\end{array}$ & Southern flying squirrel & $\begin{array}{l}43 \\
19\end{array}$ & Raleigh, N.C., & $9 / 72$ \\
\hline GV 212 & (Glaucomys volans) & & residential & \\
\hline ATCC 29061 & & 21 & & \\
\hline DM 24, -81 & $\begin{array}{l}\text { Opossum } \\
\quad \text { (Didelphis virginiana) }\end{array}$ & 4 & $\begin{array}{l}\text { Sunbury, N.C., } \\
\text { swamp }\end{array}$ & $8 / 72$ \\
\hline $\begin{array}{l}\text { ATCC } 29059, \text { DM } 30,-71 \text {, } \\
-88,-91\end{array}$ & & 5 & & \\
\hline $\mathrm{DM} 25$ & & 10 & $\begin{array}{l}\text { Sunbury, N.C., } \\
\text { woodland }\end{array}$ & \\
\hline DM 393 & & 35 & $\begin{array}{l}\text { Sunbury, N.C., } \\
\text { swamp }\end{array}$ & $12 / 72$ \\
\hline PL 37 & $\begin{array}{l}\text { Raccoon } \\
\quad(\text { Procyon lotor })\end{array}$ & 8 & & $8 / 72$ \\
\hline CF 3 & $\begin{array}{l}\text { Dog } \\
\text { (Canis familiarus) }\end{array}$ & 1 & $\begin{array}{l}\text { Raleigh, N.C., } \\
\text { residential }\end{array}$ & $11 / 71$ \\
\hline OA 526 & $\begin{array}{l}\text { Sheep } \\
\text { (Ovis aries) }\end{array}$ & 2 & $\begin{array}{l}\text { Raleigh, N.C., } \\
\text { Univ. farm }\end{array}$ & $3 / 75$ \\
\hline ATCC 29060, GH 10 & $\begin{array}{l}\text { Human } \\
\quad \text { (Homo sapiens) }\end{array}$ & & Raleigh, N.C. & $7 / 71$ \\
\hline $\mathrm{KH} 30$ & & & & \\
\hline $\begin{array}{l}\text { DW } 144 \\
\text { SK } 24\end{array}$ & & & & $11 / 71$ \\
\hline $\begin{array}{l}\text { SK } 24 \\
\text { OW } 2\end{array}$ & Beach sand & & $\begin{array}{l}\text { New Brunswick, N.J. } \\
\text { Ocracoke, N.C. }\end{array}$ & $\begin{array}{l}10 / 71 \\
10 / 72\end{array}$ \\
\hline HA $10 T$ & $\begin{array}{l}\text { Marsh grass } \\
\text { (Spartina alternaflora) }\end{array}$ & & Cape Hatteras, N.C. & \\
\hline HA 12 & Beach sand & & & \\
\hline
\end{tabular}

Usually 40 to $70 \%$ of the cells of $S$. sciuri subsp. lentus occurred in tetrad arrangements, which may be the reason why Roguinsky $(8,13$; personal communication) called these organisms "Gaffkya tetragena-like."

The colonies of the two subspecies were remarkably different. Colonies of $S$. sciuri subsp. sciuri on a $\mathrm{P}$ agar medium (6) were large ( 7.0 to $11.0 \mathrm{~mm}$ in diameter), circular, smooth, glistening, opaque, raised, and, with age, developed an elevated center. The colony edge of $86 \%$ of the strains was slightly to moderately undulate. Colonies usually developed numerous pinpoint depressions near the edge within 5 to 7 days. Eighty percent of the strains produced colonies that were gray-white with a yellowish or cream-colored tint toward the center, $14 \%$ produced yellowish or gray-yellow colonies (see color photograph of strain GH 9 in reference 4), and $6 \%$ produced gray-white (unpigmented) colonies. Pigment was considerably intensified during growth at low temperatures (15 to $20 \mathrm{C}$ ). Colonies of $S$. sciuri subsp. lentus were very small (2.2 to $3.0 \mathrm{~mm}$ in diameter), circular, smooth, glistening to wet in appearance, opaque, and convex. The colony edge of $67 \%$ of the strains was slightly undulate. All strains produced gray-white to white colonies.

Growth of S. sciuri subsp. sciuri occurred in the aerobic portion and $91 \%$ of the strains produced growth in the anaerobic portion of a semisolid thiogycolate medium. Twenty percent of the strains produced uniformly moderate to dense anaerobic growth, $67 \%$ produced a gra- 
dient of light to moderate to light or undetectable anaerobic growth down the tube, and one strain $(3 \%)$ produced a gradient of anaerobic growth plus individual discrete colonies. Ten percent of the strains failed to show detectable anaerobic growth. Growth of $S$. sciuri subsp. lentus occurred in the aerobic portion, but only one strain $(11 \%)$ produced detectable growth in the anaerobic portion of the thioglycolate medium. This strain produced a gradient of light to undetectable anaerobic growth down the tube.

Twenty-seven selected strains, including members of both subspecies, demonstrated weak fermentation of glucose by lowering the $\mathrm{pH}$ of a yeast extract-glucose broth from 6.8 to 5.7 to 6.0 after anaerobic incubation. All of these strains produced low amounts of L-lactic acid from glucose.

All strains grew well at $\mathrm{NaCl}$ concentrations up to $10 \%$, although strains of S. sciuri subsp. lentus grew very slowly and required 72 to $96 \mathrm{~h}$ of incubation for comparative evaluation. Strains usually grew poorly at an $\mathrm{NaCl}$ concentration of $15 \%$. The optimal growth temperature range was 25 to $35 \mathrm{C}$. All strains of $S$. sciuri subsp. sciuri grew moderately well at $15 \mathrm{C}$, whereas strains of $S$. sciuri subsp. lentus grew poorly or failed to grow at this temperature. Sixty-three percent of $S$. sciuri subsp. sciuri strains grew poorly and $26 \%$ failed to grow at 45 C. All $S$. sciuri subsp. lentus strains failed to grow at $45 \mathrm{C}$.

All strains had moderate catalase activity and were positive for the benzidine test. All failed to demonstrate coagulase or hemolysin activity. All strains reduced nitrates and demonstrated weak to moderate phosphatase activity. Ninety-one percent of the strains failed to produce acetylmethylcarbinol, and the few remaining strains produced only low amounts of this compound. Ninety-eight percent of the strains had weak to moderate DNase activity, and $68 \%$ failed to demonstrate bacteriolytic activity.

Thirty-one selected strains of $S$. sciuri subsp. sciuri demonstrated moderate to strong caseinolytic and gelatinase activities and failed to demonstrate lipolytic activity on triolein, tributyrin, or lecithin or elastase activity. Ninetyfour percent of the strains failed to hydrolyze Tween 80. All strains of $S$. sciuri subsp. lentus demonstrated moderate caseinolytic and gelatinase activities.

By comparison with other staphylococci, $S$. sciuri produced acid from a very wide range of carbohydrates, which included some not previously reported to be attacked by staphylococci $(4,12)$. All strains of this species produced acid, aerobically, from $\mathrm{D}-(+)$-glucose, $\beta$-D-(-)-fructose, $\mathrm{D}$ - $(-)$-ribose, $\mathrm{D}-(+)$-cellobiose, and $\mathrm{D}$-mannitol, and $68 \%$ produced small to moderate amounts of acid from maltose. In addition, all strains of $S$. sciuri subsp. sciuri produced acid from $\mathrm{D}-(+)$-galactase, $\mathrm{D}-(+)$-fucose, sucrose, and glycerol, whereas all strains of $S$. sciuri subsp. lentus produced acid from $\mathrm{D}-(++)$-mannose, sucrose, $\mathrm{D}-(+)$-trehalose, salicin, and $\beta$-gentiobiose. Ninety-one percent of $S$. sciuri subsp. sciuri strains produced acid from $\mathrm{D}-(+)$-trehalose and $\beta$-gentiobiose, $77 \%$ produced acid from D-sorbitol, $71 \%$ produced acid from salicin, $49 \%$ produced acid from $\mathrm{D}-(+)$-melezitose, $37 \%$ produced acid from $\mathrm{L}-(+)$-arabinose, $31 \%$ produced small amounts of acid from $D-(+)$-mannose, and $23 \%$ produced acid from L-(+)-rhamnose. Sixtyseven to $78 \%$ of $S$. sciuri subsp. lentus strains produced acid from $\mathrm{L}-(+)$-arabinose, $\mathrm{D}$ - $(+)$-galactose, $\alpha$-lactose, $\mathrm{L}$-(+)-rhamnose, and $\mathrm{D}$-sorbitol, and small to moderate amounts of acid from D(+)-fucose and glycerol. Eighty-nine percent of the strains of this subspecies uniquely produced acid from raffinose. One strain (3\%) of $S$. sciuri subsp. sciuri produced acid from raffinose within $24 \mathrm{~h}$, but this was neutralized by $72 \mathrm{~h}$. Six percent of $S$. sciuri subsp. sciuri strains produced a small amount of acid and $33 \%$ of $S$. sciuri subsp. lentus strains produced small to moderate amounts of acid from $D-(+)$-xylose. All strains failed to produce acid from xylitol, Darabitol, dulcitol, meso-erythritol, D-erythrose, tagatose, L-(-)-fucose, D-lyxose, or L-sorbose, and only one strain $(11 \%)$ of $S$. sciuri subsp. lentus produced small amounts of acid from D(+)-melibiose.

All strains were resistant to lysozyme. Twenty-seven percent of $S$. sciuri subsp. sciuri strains were susceptible (minimal inhibitory concentration [MIC] 25 to $50 \mu \mathrm{g} / \mathrm{ml}$ ) and $73 \%$ were slightly resistant (MIC 100 to $400 \mu \mathrm{g} / \mathrm{ml}$ ) to lysostaphin. On the other hand, all strains of $S$. scuiri subsp. lentus were very susceptible (MIC 12.5 to $25.0 \mu \mathrm{g} / \mathrm{ml}$ ) to lysostaphin. All strains were slightly resistant (MIC 1.6 to 12.5 $\mu \mathrm{g} / \mathrm{ml}$ ) to novobiocin. All strains of $S$. sciuri subsp. sciuri were slightly resistant (MIC 0.4 to $6.2 \mu \mathrm{g} / \mathrm{ml}$ ) to penicillin $\mathrm{G}$, whereas all strains of $S$. sciuri subsp. lentus were susceptible (MIC 0.05 to $0.2 \mu \mathrm{g} / \mathrm{ml}$ ) to this antibiotic. Eighty-six percent of the strains were susceptible (MIC 0.4 to $0.8 \mu \mathrm{g} / \mathrm{ml}$ ) to erythromycin.

Twenty-seven selected strains, including members of both subspecies, contained peptidoglycan of the type L-Lys-L-Ala-Gly ${ }_{4}$. In some strains of S. sciuri subsp. sciuri, small amounts of glycine are replaced by L-serine. Their cell wall teichoic acid contained glycerol and glucosamine, with the exception of one strain (DM 


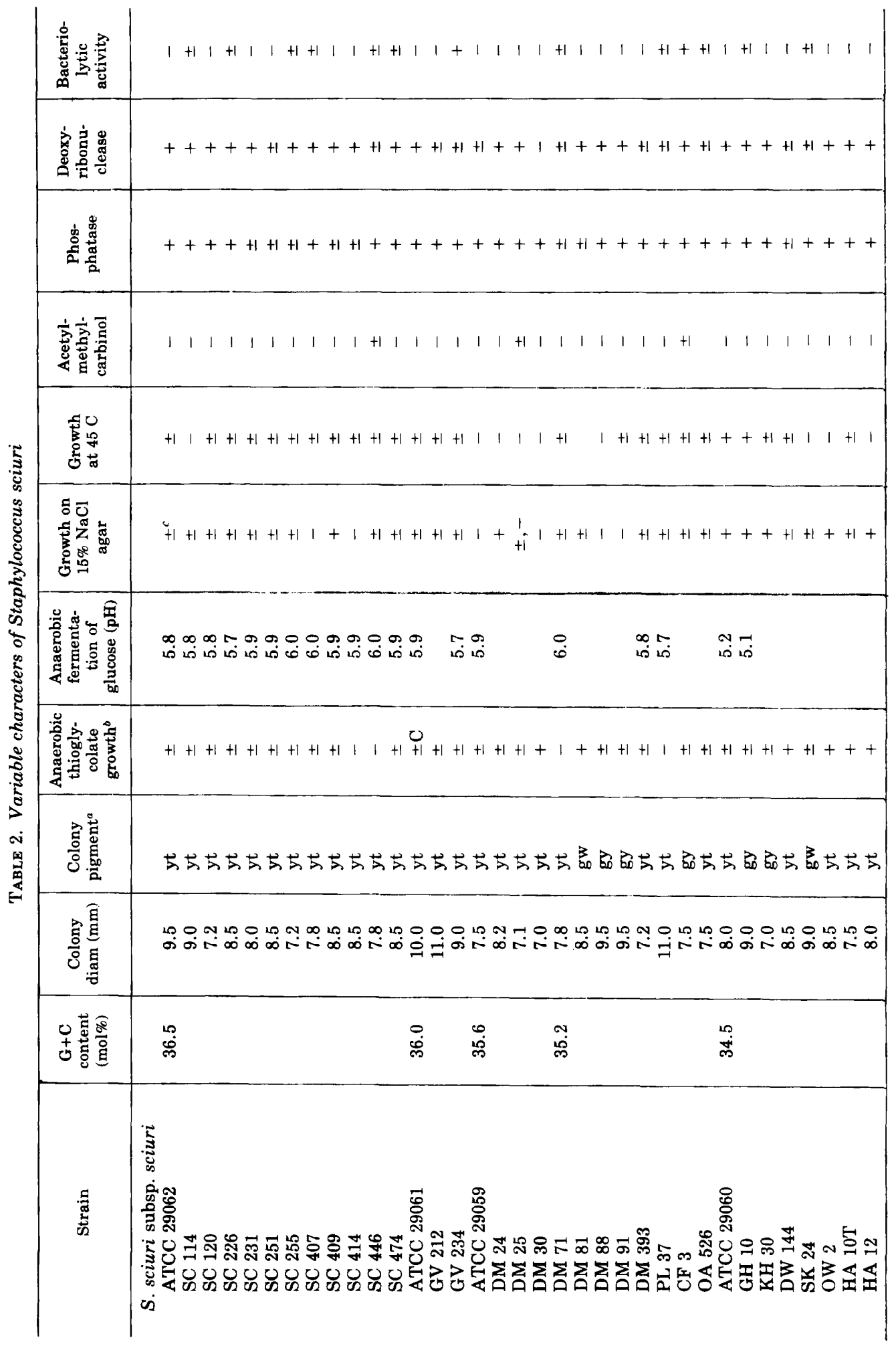




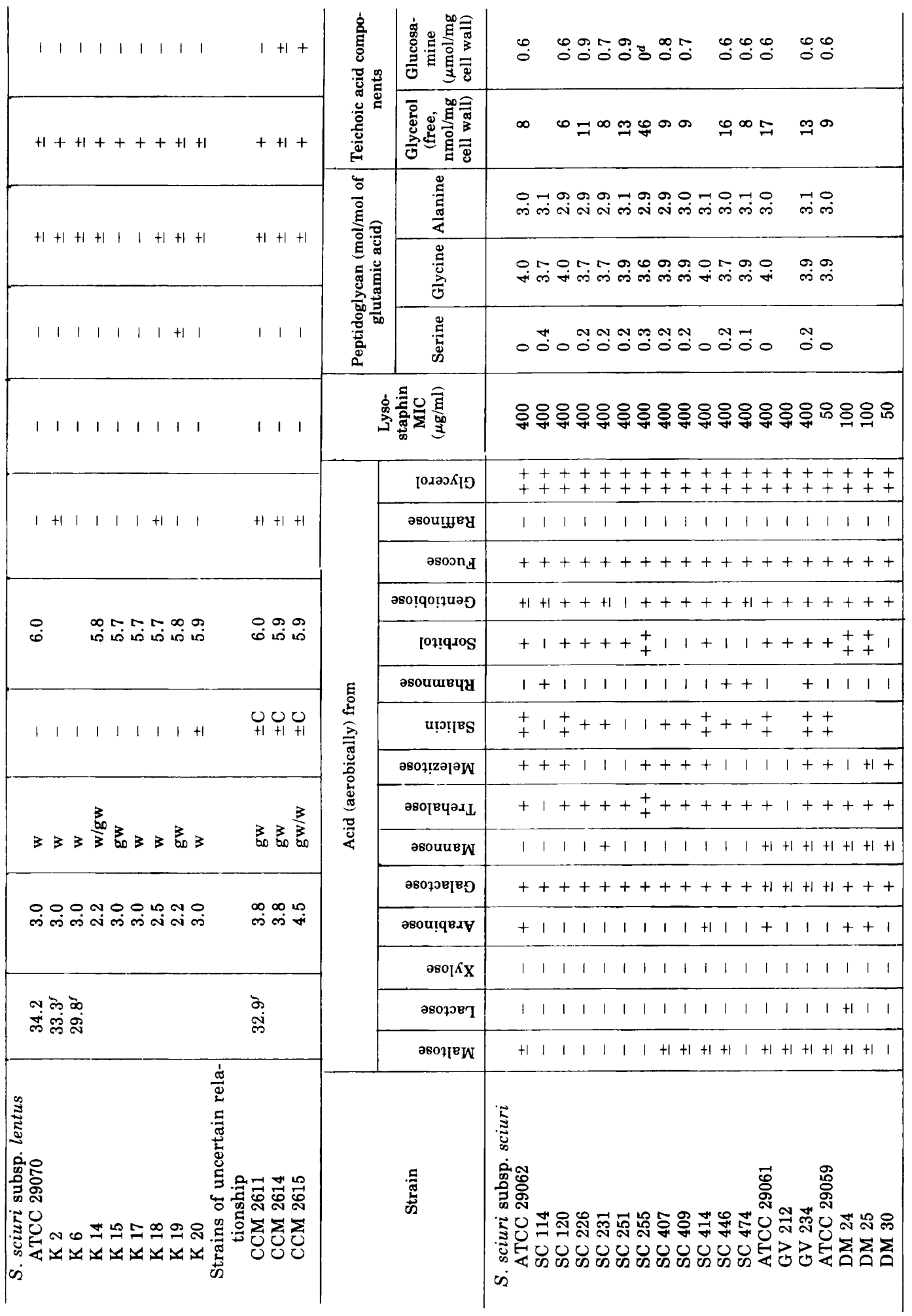




\begin{tabular}{|c|c|c|c|c|}
\hline \multirow{2}{*}{ 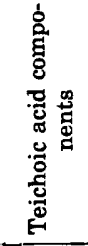 } & 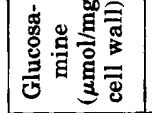 & $\ddot{0}:$ & 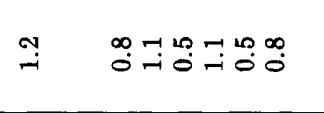 & $\tilde{0}$ \\
\hline & 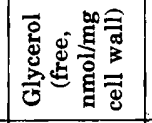 & 的至 & ชำ요용 & $の \mathfrak{⿰}$ \\
\hline \multirow{3}{*}{ 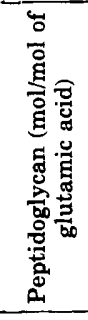 } & 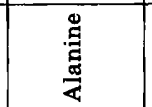 & 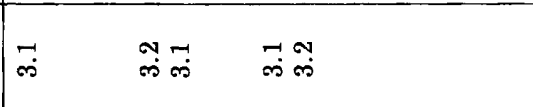 & 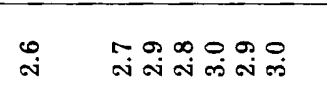 & 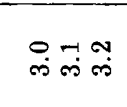 \\
\hline & 胥 & 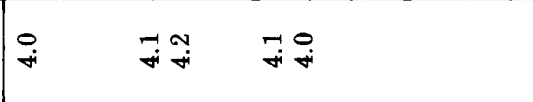 & 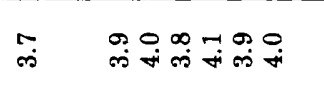 & 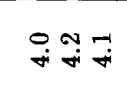 \\
\hline & 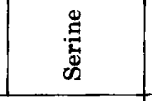 & $\begin{array}{lll}7 & 00 & 0\end{array}$ & $0 \quad 000000$ & 000 \\
\hline \multicolumn{2}{|c|}{ 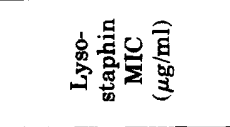 } & \multicolumn{2}{|c|}{ 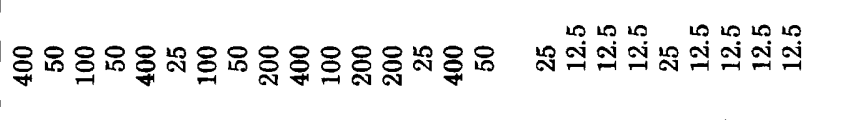 } & ผัง \\
\hline \multirow{15}{*}{ 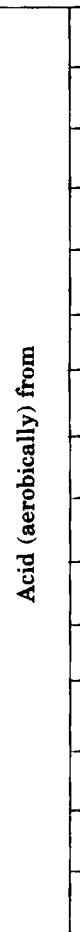 } & ןогокโD & 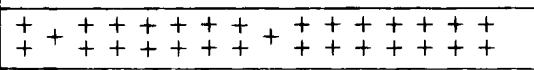 & $++1+++1+1+1$ & $\begin{array}{l}++t \\
++t\end{array}$ \\
\hline & әвоицеу & $\begin{array}{llllllllllllllll}1 & 1 & 1 & 1 & 1 & 1 & 1 & \mathbb{E} & 1 & 1 & 1 & 1 & 1 & 1 & 1 & 1\end{array}$ & $+1++1++++1+$ & 111 \\
\hline & esoon $_{4}$ & ++++++++++++++++ & $+1+1+1++1 \quad 1 \quad 1$ & +++ \\
\hline & әsọ̣qo!̣uą & $11+1+1+++++1++1+++1++1$ & +++++++ & $+1+1$ \\
\hline & Ioł!q-10S & $\begin{array}{c}+++1_{+}^{+}++++++++++ \\
+++\end{array}$ & $++++11+11+1+$ & ++ \\
\hline & әsоuसвчч & $11+++11+1111+111$ & $11+++++1$ & 111 \\
\hline & 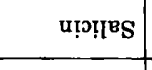 & 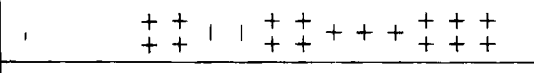 & ++++++++ & 111 \\
\hline & วsoł!̣zə[ə⿳亠口冋 & $+1+11_{+}^{+}+1111+1++11$ & $\begin{array}{llllllllll}1 & 1 & 1 & 1 & 1 & 1 & 1 & 1 & 1 \\
\end{array}$ & 111 \\
\hline & әвоГвчә.ХL & $H++1++1++++++H+++$ & $++1++++++$ & $+1+$ \\
\hline & әsouurw & 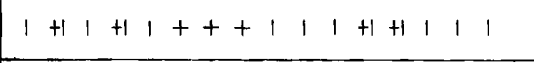 & $+1+++++++++1$ & ++ \\
\hline & 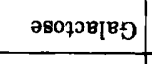 & $+++++++++++1+++++$ & $+1+++1++1+$ & $\begin{array}{lll}+1 & 1 & 1 \\
\end{array}$ \\
\hline & әsourquest & $\begin{array}{lllllll}1 & 1 & 1 & 1 & +1 & 1_{+}^{+}+++1+1 & 1 \\
\end{array}$ & $+1+ \pm+1+11+$ & 111 \\
\hline & $\operatorname{asol} \kappa \mathbf{X}$ & $\begin{array}{llllllllllllllll}1 & 1 & 1 & 1 & 1 & 1 & 1 & +1 & 1 & 1 & 1 & 1 & +1 & 1 & 1 & 1 \\
\end{array}$ & $11+1++111111$ & $+1 \quad 1 \quad 1$ \\
\hline & әвочอвт & $11+11111+1111111+11$ & $+++++++11+$ & +11 \\
\hline & อвоэген & $A+1+1+1+1+1+t+1+1+1+1+1+1+1$ & $1++++1+1+1$ & +11 \\
\hline & 䔍 & 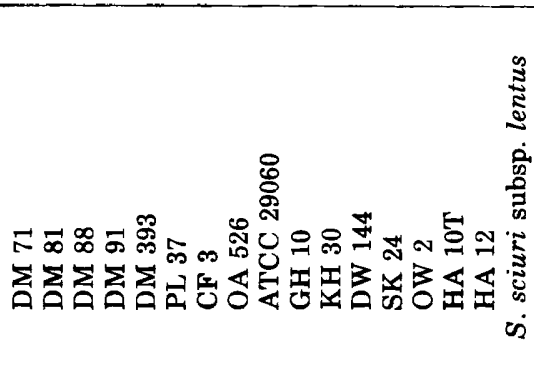 & $\begin{array}{ll}3 & \\
0 & \end{array}$ & 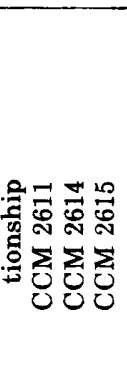 \\
\hline
\end{tabular}


71), which contained ribitol instead of glycerol, and one strain (SC 225) which contained glucose instead of glucosamine. Most of the strains of $S$. sciuri subsp. sciuri produced low concentrations of free glycerol in the acid hydrolysates of cell walls; this finding might suggest the presence of an atypical teichoic acid $(1,2)$.

The $\mathrm{G}+\mathrm{C}$ content of the DNA, as determined in six strains, was $35.3 \pm 0.4 \mathrm{~mol} \%$.

$S$. sciuri can be distinguished from all other staphylococci primarily on the basis of its distinctive colonial morphology, carbohydrate reaction pattern (including the unique production of acid from fucose and cellobiose), cell wall peptidoglycan, and a combination of characteristics including novobiocin resistance, L-lactic acid configuration, lack of acetylmethylcarbinol production, weak to moderate phosphatase and DNase activites, nitrate reduction, moderate to strong caseinolytic and gelatinase activities, and lack of lipolytic activity. There are also some significant differences between $S$. sciuri and certain other species in the parameters of growth at extreme temperatures and different $\mathrm{NaCl}$ concentrations, cell arrangement, growth in a thioglycolate medium, and coagulase, hemolysin, and bacteriolytic activities. Several of the above-mentioned properties appear to overlap with those of S. xylosus, suggesting a relatively close relationship between these species. Some variable characters and the $\mathrm{G}+\mathrm{C}$ contents of the DNAs of representative strains of $S$. sciuri are given in Table 2 .

Description of the type strain of S. sciuri subsp. sciuri. Strain ATCC 29062 (originally designated SC 116), isolated from the skin of an Eastern gray squirrel, is the type strain of $S$. sciuri subsp. sciuri, the type subspecies of $S$. sciuri. A description of this strain follows.

Cells: Spheres, 0.8 to $1.2 \mu \mathrm{m}$ in diameter, occurring in pairs, singly, and in tetrads, in order of frequency. Nonmotile and nonsporeforming. Gram positive.

Agar colonies: Circular, 9.0 to $9.5 \mathrm{~mm}$ in diameter, moderately undulate edge, raised with slightly elevated center, smooth with glistening surface. Opaque, gray-white with cream tint toward center.

Catalase and benzidine tests are positive.

Chemoorganotroph; metabolism is respiratory.

Facultatively anaerobic.

Growth at extreme temperatures: Moderate growth at $15 \mathrm{C}$, poor growth at $45 \mathrm{C}$.

Growth on $\mathrm{NaCl}$ agar: Good growth with $10 \%$

$\mathrm{NaCl}$, poor growth with $15 \%$.

Coagulases are not produced.

Phosphatase activity is moderate. 
Nitrates are reduced.

Hemolysins: No hemolysis of bovine blood.

Acetylmethylcarbinol is not produced.

DNase activity is moderate.

Proteolytic activity: Caseinolysis is strong, gelatinase activity is moderate, and there is no elastase activity.

Lipolytic activity: No lipolysis of triolein, tributyrin, or Tween 80; no lecithinase activity.

Acid produced aerobically from $\mathrm{D}-(+)$-glucose, $\beta$-D-(-)-fructose, $\mathrm{D}$ - $(+)$-galactose, $\mathrm{D}-(+)$-fucose, $\mathrm{D}-(-)$-ribose, sucrose, $\mathrm{D}-(+)$-cellobiose, $\mathrm{D}-$ mannitol, glycerol, L-(+)-arabinose, D-(+)-trehalose, $\mathrm{D}-(+)$-melezitose, salicin, and D-sorbitol; small amounts of acid are produced from $\beta$ gentiobiose and maltose. No acid from $\alpha$-lactose, $\mathrm{D}-(+)$-xylose, $\mathrm{D}-(+)$-mannose, $\mathrm{L}-(+)$-rhamnose, $\mathrm{D}$-(+)-turanose, xylitol, meso-inositol, adonitol, dulcitol, D-arabitol, meso-erythritol, D-erythrose, raffinose, D-(+)-melibiose, tagatose, D-lyxose, or L-sorbose.

Antibiotic, lysostaphin, and lysozyme susceptibilities: Slightly resistant to penicillin G (MIC $1.6 \mu \mathrm{g} / \mathrm{ml}$ ), novobiocin (MIC $12.5 \mu \mathrm{g} / \mathrm{ml}$ ), streptomycin (MIC $25 \mu \mathrm{g} / \mathrm{ml}$ ), and tetracycline (MIC $6.2 \mu \mathrm{g} / \mathrm{ml}$ ); susceptible to erythromycin (MIC $0.8 \mu \mathrm{g} / \mathrm{ml}$ ); slightly resistant to lysostaphin (MIC $400 \mu \mathrm{g} / \mathrm{ml}$ ); resistant to lysozyme.

Cell wall peptidoglycan: L-Lys-L-Ala-Gly ${ }_{4}$.

Cell wall teichoic acid: Glycerol and glucosamine.

Lactic acid configuration: L-lactic acid.

$\mathrm{G}+\mathrm{C}$ content of DNA: $36.5 \mathrm{~mol} \%$.

Description of the type strain of $S$. sciuri subsp. lentus. Strain ATCC 29070 (originally designated K21), isolated from the udder of a goat, is the type strain of $S$. sciuri subsp. lentus. A description of this strain follows.

Cells: Spheres, 0.9 to $1.2 \mu \mathrm{m}$ in diameter, occurring in tetrads and occasionally in pairs. Nonmotile and nonsporeforming. Gram positive.

Agar colonies: Circular, 2.8 to $3.0 \mathrm{~mm}$ in diameter, entire, convex, smooth, and glistening wet surface. Opaque white.

Catalase and benzidine tests are positive.

Chemoorganotroph; metabolism is respiratory.

Aerobic with very slight facultative anaerobic capability.

Growth at extreme temperatures: No growth at $15 \mathrm{C}$ or $45 \mathrm{C}$.

Growth on $\mathrm{NaCl}$ agar: Moderate growth with $10 \% \mathrm{NaCl}$, poor growth with $15 \%$.

Coagulases are not produced.

Phosphatase activity is weak.

Nitrates are reduced.

Hemolysins: No hemolysis of bovine blood.
Acetylmethylcarbinol is not produced.

DNase activity is moderate.

Proteolytic activity: Caseinolytic and gelatinase activities are moderate.

Acid produced aerobically from $\mathrm{D}$ - $(+)$-glucose, $\beta$-D- $(-)$-fructose, $\mathrm{D}-(+)$-galactose, $\mathrm{D}-(-)$-ribose, sucrose, D- $(+)$-cellobiose, D-mannitol, $\alpha$ lactose, glycerol, D-(+)-trehalose, salicin, D-sorbitol, $\beta$-gentiobiose, and raffinose; a small amount of acid is produced from $\mathrm{L}-(+)$-arabinose, $\mathrm{D}-(+)$-mannose, and $\mathrm{D}-($, )-fucose. No acid from maltose, $\mathrm{D}-(+)$-xylose, $\mathrm{D}-(+)$-turanose, $\mathrm{D}$ $(+)$-melezitose, xylitol, L-sorbose, D-arabitol, D(+)-melibiose, L-(+)-rhamnose, meso-inositol, adonitol, dulcitol, D-arabitol, meso-erythritol, D-erythrose, tagatose, D-lyxose, or L-sorbose.

Antibiotic, lysostaphin, and lysozyme susceptibilities: Slightly resistant to novobiocin (MIC $1.6 \mu \mathrm{g} / \mathrm{ml}$ ); susceptible to penicillin G (MIC 0.2 $\mu \mathrm{g} / \mathrm{ml}$ ), streptomycin (MIC $0.8 \mu \mathrm{g} / \mathrm{ml}$ ), tetracycline (MIC $0.4 \mu \mathrm{g} / \mathrm{ml}$ ), and erythromycin (MIC $1.6 \mu \mathrm{g} / \mathrm{ml}$ ); susceptible to lysostaphin (MIC 25 $\mu \mathrm{g} / \mathrm{ml})$; resistant to lysozyme.

Cell wall peptidoglycan: L-Lys-L-Ala-Gly ${ }_{4}$.

Cell wall teichoic acid: Glycerol and glucosamine.

Lactic acid configuration: L-lactic acid.

$\mathrm{G}+\mathrm{C}$ content of DNA: $34.2 \mathrm{~mol} \%$.

Summary of character variation in S. sciuri and other novobiocin-resistant species. Summary data of the morphological, physiological, biochemical, and antibiotic characters found in S. sciuri and other presumably related novobiocin-resistant Staphylococcus species, namely S. xylosus, S. cohnii, and S. saprophyticus, are given in the following tables: colony morphology and pigment and cell arrangements, Table 3; anaerobic growth in thioglycolate, growth on $10 \%$ and $15 \% \mathrm{NaCl}$ agar, and growth at 15 and $45 \mathrm{C}$, Table 4; hemolysin activity, acetylmethylcarbinol production, nitrate reduction, phosphatase, DNase, and bacteriolytic activities, Table 5; carbohydrate reactions, Tables 6, 7 and 8; lysostaphin and antibiotic susceptibilities, Table 9; proteolytic and lipolytic activities, Table 10 . The summary data on strains of S. xylosus, S. cohnii, and S. saprophyticus isolated from human skin have been published previously $(4,12)$. They are used here for making comparisons with similar species isolated from animal skin and with $S$. sciuri, a species isolated predominantly from animals.

As can be seen from the data on various characters, $S$. xylosus and $S$. sciuri strains isolated from animals had character parameters similar to strains isolated from humans. However, some question arises as to the original 


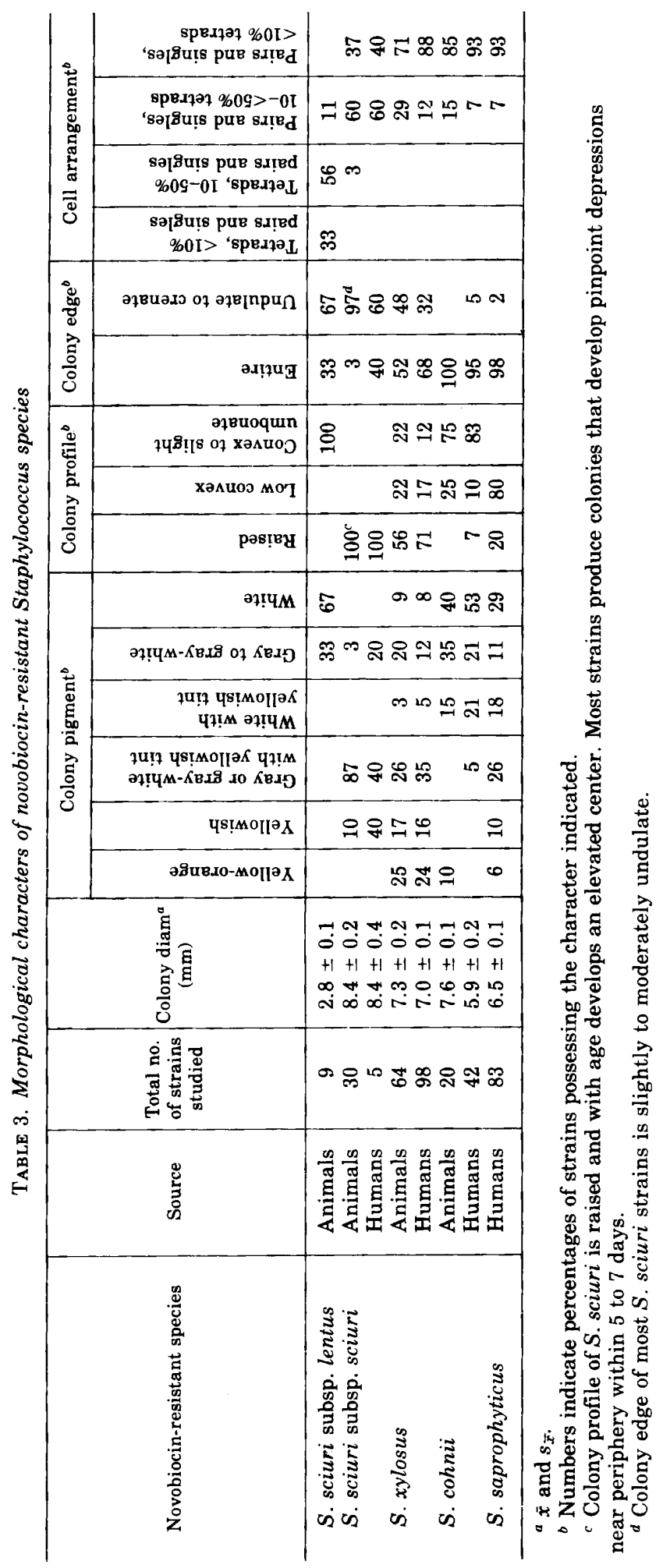




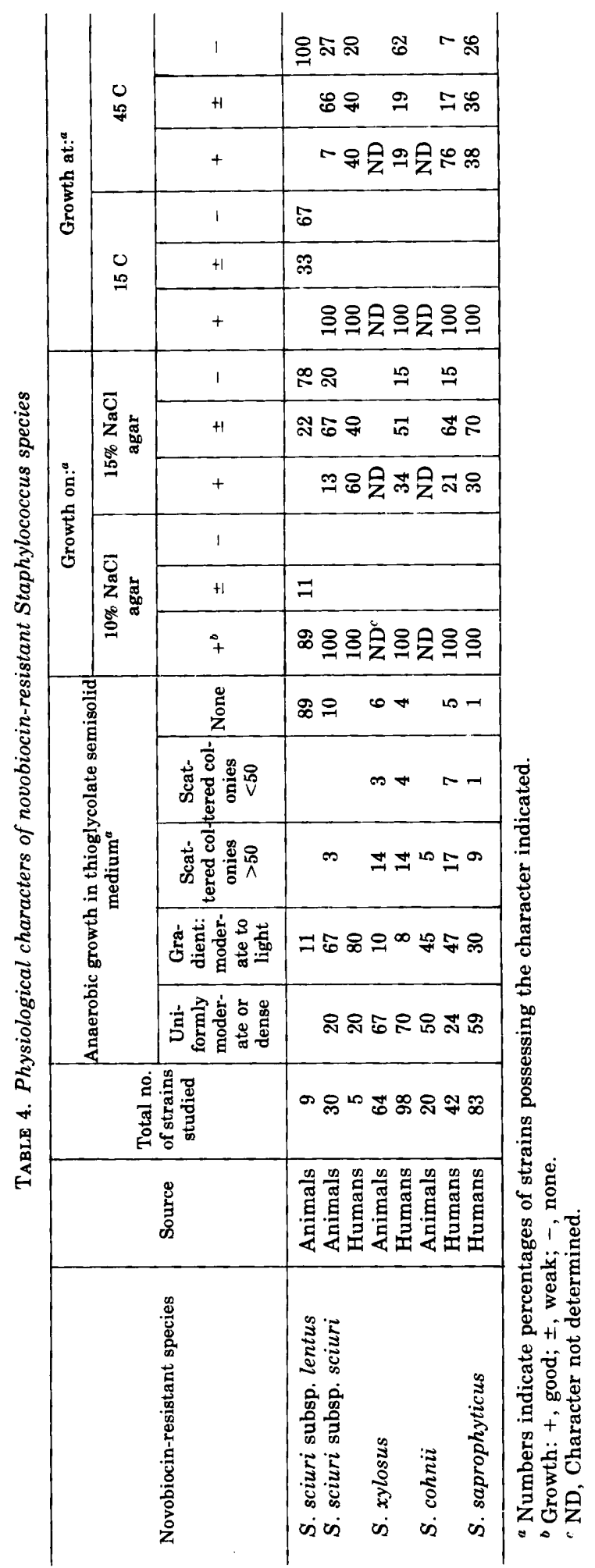



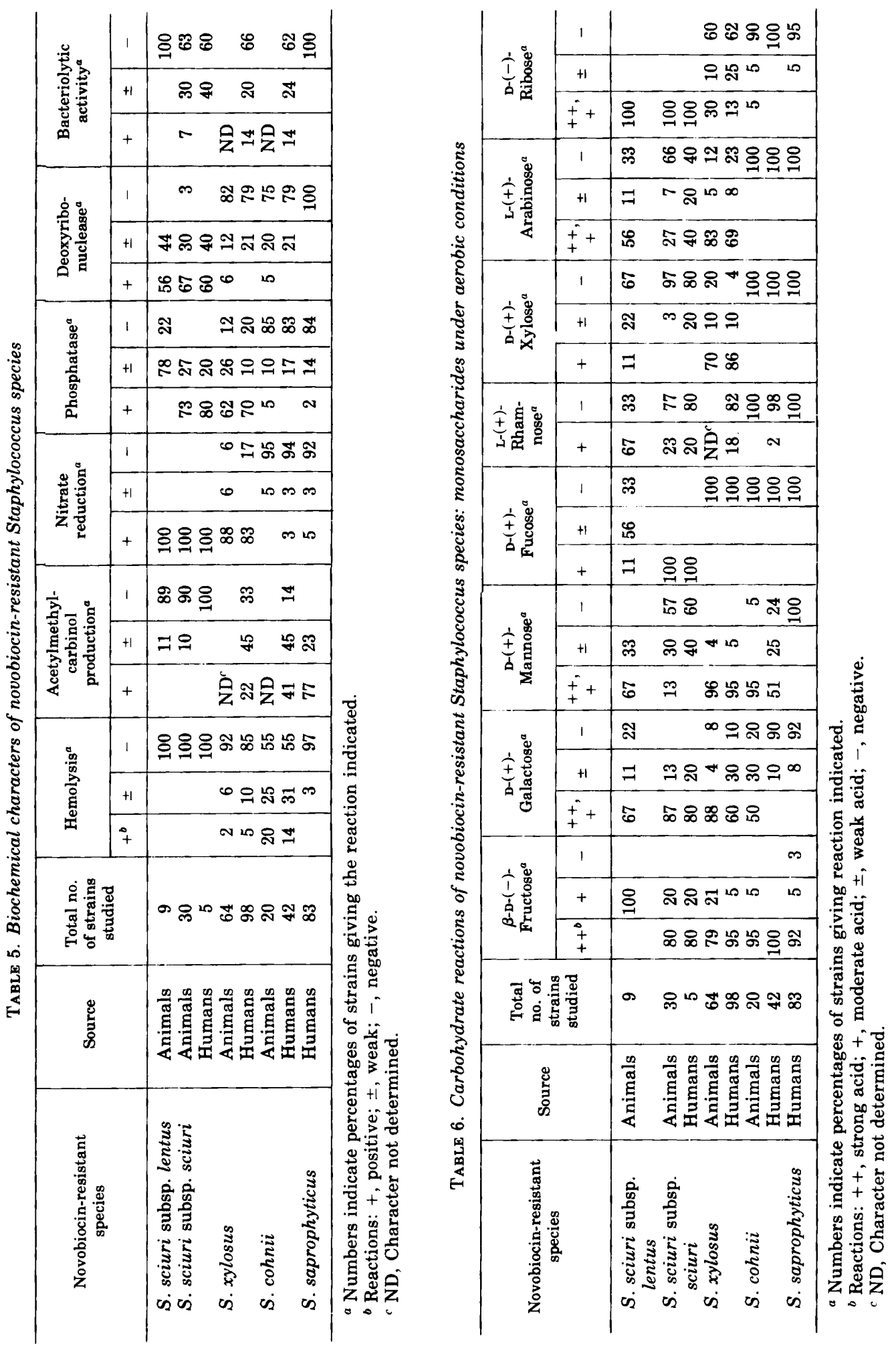

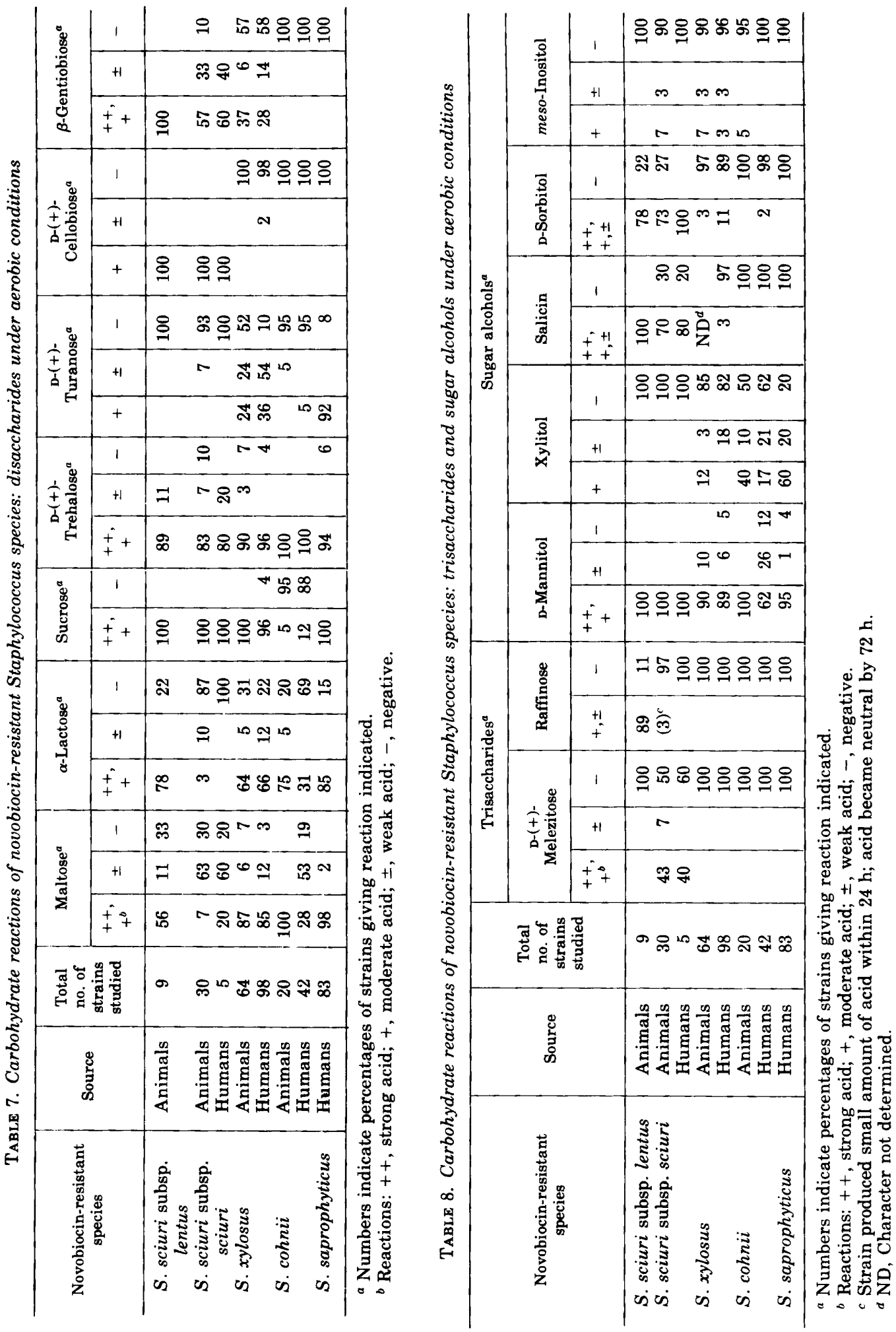


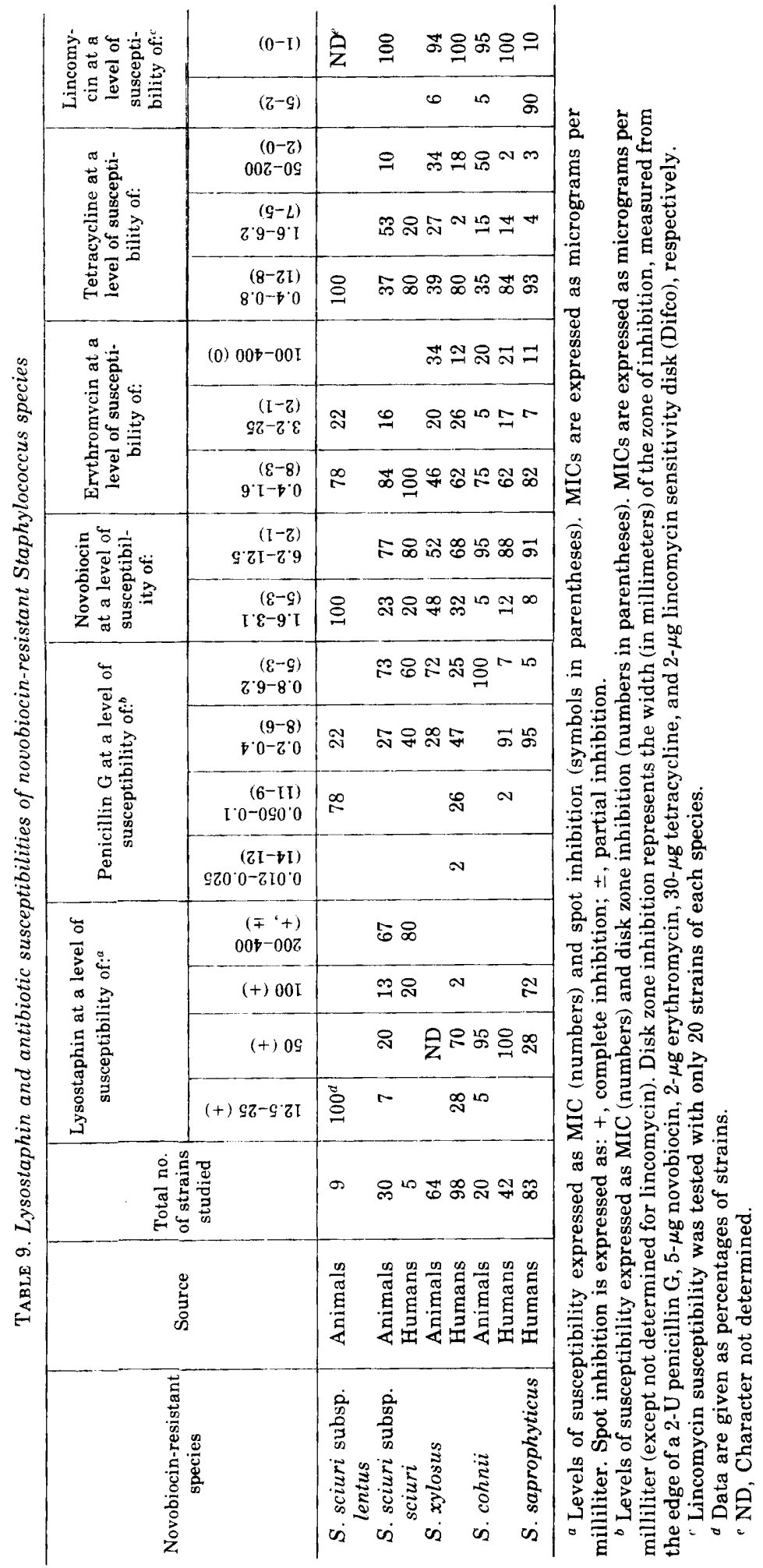


INT. J. Syst. Bacteriol.
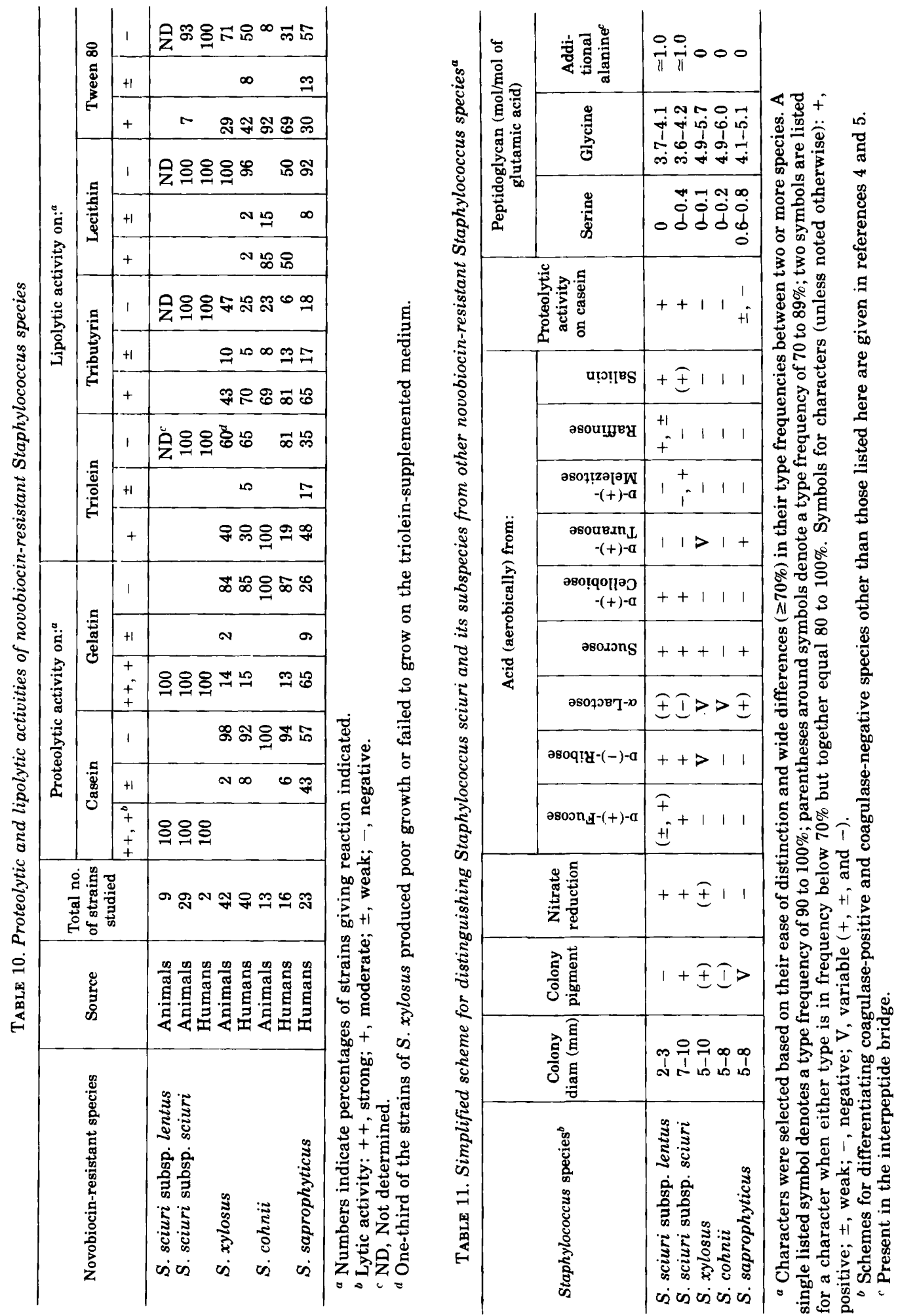
source of $S$. xylosus and $S$. sciuri strains isolated from humans. Humans from whom these species were isolated had several pets or had frequent contact with farm animals, whose staphylococci may have contaminated their skin.

$S$. cohnii strains isolated from animals had several noteworthy differences in character parameters compared to strains isolated from humans, particularly with respect to colony size, certain carbohydrate reactions, lipolytic activity, and antibiotic susceptibilities. These differences might suggest a significant divergence between strains of $S$. cohnii living on animals and those living on humans.

A simplified scheme distinguishing S. sciuri and its subspecies from other noviobiocin-resistant Staphylococcus species is shown in Table 11.

\section{ACKNOWLEDGMENTS}

We are greatly indebted to M. Musselwhite, L. Hagner, B. Popp, and D. Blasi for their excellent technical assistance throughout this study. We are also thankful for the assistance provided by $R$. Zimmerman, M. Huish, L. Platner, B. S. Martof, L. F. Kloos, C. H. Bostian, H. R. Perry, and L. Goode in collecting staphylococci from animal skins and by Renee Johnson in assembling and typing tabular data for the manuscript.

This research was supported by Public Health Service research grant AI 08255 from the Institute of Allergy and Infectious Diseases, by a grant from the Deutsche Forschungsgemeinschaft, and by the Shriners of North America.

\section{REPRINT REQUESTS}

Address reprint requests to: Dr. Wesley E. Kloos, Dept. of Genetics, North Carolina State University, Box 5487, Raleigh, N. C. 27607

\section{LITERATURE CITED}

1. Archibald, A. R., J. Baddiley, and D. Button. 1968. The glycerol teichoic acid of walls of Staphylococcus lactis I3. Biochem. J. 110:543-557.

2. Archibald, A. R., J. Baddiley, J. E. Heckels, and S. Heptinstall. 1971. Further studies on the glycerol teichoic acid of walls of Staphylococcus lactis I3. Location of phosphodiester groups and their susceptibility to hydrolysis with alkali. Biochem. J. 125:353 359 .
3. Davison, A. L. 1968. The characterizaton of a Micrococcus (Staphylococcus lactis) sp. 13 with an atypical teichoic acid in its cell wall. Biochem. J. 110:557-558.

4. Kloos, W. E., and K. H. Schleifer. 1975. Isolation and characterization of staphylococci from human skin. II. Descriptions of four new species: Staphylococcus warneri, Staphylococcus capitis, Staphylococcus hominis, and Staphylococcus simulans. Int. J. Syst. Bacteriol. 25:62-79.

5. Kloos, W. E., and K. H. Schleifer. 1975. Simplified scheme for routine identification of human Staphylococcus species. J. Clin. Microbiol. 1:82-88.

6. Kloos, W. E., T. G. Tornabene, and K. H. Schleifer. 1974. Isolation and characterization of micrococci from human skin, including two new species: Micrococcus lylae and Micrococcus kristinae. Int. J. Syst. Bacteriol. 24:79-101.

7. Kocur, M., and J. Boháček. 1974. DNA base composition and the classification of non-pigmented micrococci. Microbios 10:31-38.

8. Kocur, M., and T. Martinec. 1972. Taxonomic status of Micrococcus varians Migula 1900 and designation of the neotype strain. Int. J. Syst. Bacteriol. 22:228232.

9. Martley, F. G., S. R. Jayashankar, and R. C. Lawrence. 1970. An improved medium for the detection of proteolytic organisms in total bacterial counts. J. Appl. Bacteriol. 33:363-370.

10. Schleifer, K. H., and O. Kandler. 1967. Zur chemischen Zusammensetzung der Zellwand der Streptokokken. I. Die Aminosäuresequenz des Mureins von Streptococcus thermophilus und Streptococcus faecalis. Arch. Mikrobiol. 57:335-364.

11. Schleifer, K. H., and O. Kandler. 1972. The peptidoglycan types of bacterial cell walls and their taxonomic implications. Bacteriol. Rev. 36:407-477.

12. Schleifer, K. H., and W. E. Kloos. 1975. Isolation and characterization of staphylococci from human skin. I. Amended descriptions of Staphylococcus epidermidis and Staphyococcus saprophyticus, and descriptions of three new species:Staphylococcus cohnii, Staphylococcus haemolyticus, and Staphylococcus xylosus. Int. J. Syst. Bacteriol. 25:50-61.

13. Schleifer, K. H., and M. Kocur. 1973. Classification of staphylococci based on chemical and biochemical properties. Arch. Mikrobiol. 93:65-85.

14. Smith, R. F., and C. L. Bettge. 1972. Comparative characteristics of human and porcine staphylococci and their differentiation in burn xenografting procedures. Appl. Microbiol. 24:929-932.

15. Varadi, D. P., and A. C. Saqueton. 1970. Perifollicular elastolysis. Br. J. Dermatol. 83:143-150.

16. Wolin, M. J., A. R. Archibald, and J. Baddiley. 1966. Changes in wall teichoic acid resulting from mutations of Staphylococcus aureus. Nature (London) 209:484-486. 